\title{
Hindu-Buddhis Dalam Bingkai Budaya Jawa Asli
}

\author{
Baskoro Daru Tjahjono
}

Keywords: culture, acculturation, assimilation, Java, classic, India

\section{How to Cite:}

Tjahjono, B. D. Hindu-Buddhis Dalam Bingkai Budaya Jawa Asli. Berkala Arkeologi, 15(1), 1-9. https:/ / doi.org/10.30883/jba.v15i1.650

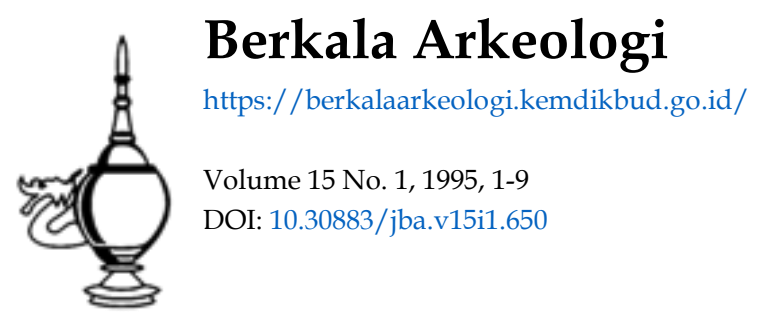

\section{(c) (1) (2)(2)}

This work is licensed under a Creative Commons Attribution-NonCommercial-ShareAlike 4.0 International License. 


\title{
HINDU-BUDDHIS DALAM BINGKAI BUDAYA JAWA ASLI
}

\author{
Baskoro D. Tjahjono \\ (Balai Arkeologi Yogyakarta)
}

\section{Pendahuluan}

Agama Hindu dan Buddha berasal dari India, masuk ke Indonesia hampir bersamaan waktunya yaitu sekitar abad pertama masehi. Kebudayaan yang berasal dari India tersebut sering disebut dengan istilah kebudayaan Hindu saja. Pengaruh kebudayan itu selain telah mengantarkan bangsa Indonesia memasuki jaman sejarah juga telah memba-wa perubahan besar dalam berbagai aspek kehidupan, seperti agama, struktur pemerintahan, dan aspek kehidupan masyarakat yang lain.

Kedua agama itu mengalami perkembangan pesat pada masa Jawa Tengah (abad VIII-X M). Dalam perkembangan selanjutnya, bersamaan dengan berpindahnya pusat pemerintahan ke Jawa Timur, telah terjadi "sinkretisme" antara kedua agama tersebut. Istilah sinkretisme di sini tidak dimaksudkan untuk menyatakan bahwa telah terjadi pelebur-an diantara keduanya, tetapi ke-dua agama tersebut tetap berdiri sendi-risendiri dengan pengikutnya masing-masing. Beberapa ahli memang belum sepakat dengan istilah tersebut, diantaranya Pigeaud yang mengusulkan istilah parallelism, Gonda menggunakan istilah coalition, dan Kern menggunakan istilah vermenging (percampuran). Namun dibalik perkembangan serta kebesaran agama Hindu dan buddha tersebut apa yang terjadi pada budaya Indonesia (Jawa) asli. Tulisan ini mencoba untuk menelaah apa yang terjadi dibalik perkembangan Hindu-Buddhis, khususnya sekitar abad XI - XV Masehi.

\section{Sinkretisme Hindu-Buddha Pada Masa Jawa Timur}

Masa Majapahit dipandang sebagai puncak sinkretisme agama Hindu dan Buddha. Proses penyatuan agama Hindu dan Buddha sebenarnya sudah dimulai sejak masa Jawa Tengah, dan mengalami perkembangan pada masa Jawa Timur. Antara Dewa Çiwa dengan segala penjelmaannya dan Buddha dengan segala penjelmaannya dianggap tidak ada lagi perbedaannya (Harun Hadiwijono, 1975: 96-97).

Pada masa Majapahit terdapat dua buah kakawin besar, yaitu Arjunawijaya dan Sutasoma (Porusádas'ânta). Kedua kakawin itu ditulis oleh Mpu Tantular pada masa pemerintahan Raja Hayam Wuruk. Dari 
keduanya dapat diketahui bahwa pada hakekatnya Dewa Çiwa dan Buddha adalah sama.

Dalam kakawin Arjunawijaya ada bagian yang menceritakan Raja Arjuna Sahasrabåhu ketika memasuki sebuah tempat ibadat agama Buddha mendapat keterangan tentang arca-arca yang ada di dalam candi dari bhiksu yang mengantarnya. dijelaskan bahwa arca besar di tengah menggambarkan Wairocana, yang sama dengan Sadâsîwa. Aksobhya di bagian timur sama dengan Rudra. Ratnasambhawa di bagian selatan sama dengan Brahmå. Amitâbha di bagian barat sama dengan Mahådewa. Amoghasiddhi di utara sama dengan Wisnu (PJ. Zoetmulder, 1983:412-413). Keterangan itu terdapat dalam pupuh 26.4 dan 27.1, yang berbunyi sebagai berikut (Supomo, 1977. 122-123):

"... san hyan Wairocanâtyanta Jinapati winimbárcágên i tênah, lilábodhyagrimudránupanna sira katon sáksât S'iwasadá."

(pupuh 26.4)

"Aks obhya purwa sira têki bhat ára Rudra, hyan Ratnasambhawa ri daks in a Dhatrdewa, s'an s'ry Amitábha sira pascima dewa máhá, s'ry Amoghasiddhi sira lor Harimurtidewa."

(pupuh 27.1)

Dalam kakawin Sutasoma diceritakan tentang kemarahan Porusåda yang telah menjelma menjadi Rudra atau Çiwa, dan hendak membinasakan Sutasoma yang merupakan inkarnasi Buddha. Oleh karena itu para dewa segera turun ke bumi dan mencoba meredakan kema-rahan Çiwa, dengan mengingatkan bahwa Buddha dan Çiwa pada ha-kekatnya tunggal (PJ. Zoetmulder, 1983:428). ".. mangká Jinatwa la-wan Çiwatatwa tunggal, bhinneka tunggal ika tan hana dharmma mang-rwa." (Soewito Santosa, 1975: 579).

Selain kedua kakawin yang ditulis Mpu Tantular itu, keterangan tentang adanya persamaan antara dewa Çiwa dan Buddha juga dijumpai dalam kakawin Kuñjarakarna. Di dalam kakawin itu disebutkan tidak ada seorang pun, baik pengikut Çiwa maupun Buddha yang dapat mencapai kelepasan jika memisahkan apa yang sebenarnya satu, yaitu Çiwa-Buddha (PJ. Zoetmulder, 1983:473).

"ngwang Wairocana buddhamurti s'iwamurti

pinakaguru ning jagat kabeh. 
nâhan donkw ingaran bhat âra guru kaprakas'ita

têka ring sarat kabeh,

anghing byâpaka ring samastabhuwanâku

juga warawis'esadewatá." (Teeuw, et al.,1981:124)

Bukti-bukti arkeologis adanya sinkretisme agama Hindu dan Buddha juga tampak pada beberapa bangunan masa Jawa Timur, misalnya candi Jawi dan candi Jago. Candi Jawi yang merupakan salah satu bangunan pendharmaan raja Krtanågara, pada bagian bawah bersifat Çiwais, sedangkan bagian atas bersifat Buddhis. Di dalam kitab Nâgarakrtâgama pupuh 56.2 dikatakan: "Cihnang candi risor kaçaiwan apucak kaboddhan i ruhur." (Pigeaud,1960:42). Pada candi Jago, yang merupakan tempat pendharmaan Raja Wisnuwardhana, terdapat relief-relief dengan latar belakang agama yang berbeda. Cerita Tantri dan Kuñjarakarna mewakili agama Buddha, sedangkan cerita Parthayajña, Kresnayana, dan Arjunawiwaha mewakili agam Hindu. Sekalipun demikian, Kern dalam bukunya berjudul Over de vermenging van Çivaisme en Buddhisme op Java naar aanleiding van het Oudjavaansch gedicht Sutasoma, mengingatkan bahwa meskipun agama Hindu dan Buddha dalam pengertiannya yang lebih dalam sama, namun keduanya tidak pernah lebur menjadi satu. Keduanya tetap berbeda satu sama lain, meskipun para penganutnya hidup berdampingan secara damai (JHC. Kern,1982:31). Oleh karena itu dalam masalah ini Kern hanya menggunakan istilah vermenging (percampuran).

\section{Hindu-Buddhis Dalam Bingkai Budaya Jawa Asli}

Selain adanya sinkretisme agama Hindu dan Buddha yang menonjol pada masa Jawa Timur, tampak pula unsur-unsur Indonesia asli pa-da hasil-hasil seni Hindu dan Buddha. Misalnya dalam seni bangunan, susunan halaman candi tidak lagi memusat melainkan berderet ke belakang. Menurut Soekmono, susunan tersebut merupakan proyeksi datar dari susunan vertikal, dengan tujuan pengarahan perhatian ke lokasi nenek moyang di gunung-gunung ( $R$. Soekmono,1986:237-238). Penggambaran arca, khususnya pada masa Majapahit, tampak kaku tanpa ekspresi. Hal ini dimaksudkan untuk menggambarkan seseorang yang telah meninggal. Menurut Stutterheim sifat-sifat arca yang kelihatan seperti mummy itu kemungkinan menunjukkan potret seorang raja (WF. Stutterheim,1931:6). Arca-arca demikian merupakan arca perwujudan leluhur. Demikian pula relief-relief ceritanya, yang dipahatkan pada can-di tidak lagi bercorak naturalis melainkan simbolis, yaitu pipih menye-rupai 
bentuk wayang kulit. Corak demikian merupakan ciri khas Indo-nesia. Penggambaran tokoh dengan bentuk tubuh pipih yang digambarkan tampak depan, kepala dan kaki menghadap ke samping, bentuk tokoh yang menyeramkan, serta pengiring-pengiringnya yang berbentuk jelek menunjukkan sifat-sifat bentuk wayang yang merupa-kan gambaran dari dunia arwah (AJ. Bernet Kempers,1959:23). Muncul-nya unsur-unsur Indonesia asli itu tentunya berhubungan dengan per-kembangan keagamaan yang terjadi pada masa itu, sebab pada ke-nyataannya hasilhasil seni tersebut memang bernafaskan keagamaan.

Sehubungan dengan munculnya unsur-unsur Indonesia asli, suatu pernyataan yang menarik telah dikemukakan oleh Rassers dalam karangannya yang berjudul Çiva en Boeddha iı den Indischen Archipel (WH. Rassers, 1982:37-40). Rassers mengatakan bahwa peranan kebudayaan Jawa asli besar dalam percampuran Çiwaisme dan Buddhisme di Jawa, khususnya pada masa Jawa Timur, meskipun percampuran atau sinkretisme itu bukan khas Jawa saja (Sinkretisme Çiva dan Bud-dha terdapat di Kamboja, Nepal, dan India; J. Gonda, 1970:27).

Rassers menganalisis cerita Bubukshah dan Gagang Aking serta berpendapat inti cerita itu merupakan sebuah mitos nenek moyang, yaitu dongeng tentang kejadian suku. Tokoh-tokoh cerita itu sebelum berganti nama menjadi Bubukshah dan Gagang Aking adalah Kébong-rawég dan Kébo-milih. Nama-nama itu merupakan nama-nama dari ke-dua leluhur kerajaan Jawa. Gagang Aking yang menempati tempat kiri dan dianggap saudara tua dipersamakan dengan pendeta Çiwa, se-dangkan Bubukshah yang di kanan dan dianggap saudara muda diper-samakan dengan pendeta Buddha. Persamaan ini dilakukan untuk me-nyesuaikan mitos nenek moyang tersebut dengan keadaan yang berla-ku masa itu, yaitu masa Hindu-Jawa di Jawa Timur. Dengan kata lain, dalam perkembangan masyarakat Jawa Hindu, kedua agama besar yang berasal dari India telah dimasukkan ke dalam kerangka pemikiran Jawa asli. Lebih lanjut Rassers mengatakan bahwa pada masa Jawa Timur Çiwaisme dan Buddhisme hanyalah merupakan aspek dari satu agama tunggal yang berpangkal pada kepercayaan Jawa Kuna (W.H. Rassers, 1982: 56-64).

Puncak dari perkembangan agama tersebut terjadi pada masa Majapahit akhir, yang juga merupakan saat-saat akhir periode klasik Indonesia. Pada masa itu telah tumbuh dan berkembang suatu kultus baru, yaitu pemujaan kepada sesuatu yang dianggap mempunyai ke-kuatan magis. Oleh para penganutnya kekuatan tersebut dipakai seba-gai 
lambang untuk memperoleh kesuburan maupun untuk mencapai kesempurnaan hidup atau membebaskan diri dari ikatan keduniawian. Dalam perkembangannya kultus itu biasanya tumbuh di suatu daerah yang berada jauh dari pusat kerajaan, misalnya di lereng-lereng gunung (Sri Soejatmi Satari,1975:11). Kultus baru yang muncul pada masa Majapahit akhir itu misalnya kultus Bhima. Menurut Stutterheim, Bhima muncul sebagai tokoh yang dikultuskan karena dia selalu berhasil menyelamatkan seseorang dari suatu malapetaka. Di samping itu dia dipandang sebagai tokoh yang paling jelas mempunyai sifat mistik-magis. Selanjutnya disebutkan pula bahwa kehadiran tokoh Bhima itu berkait-an dengan tampilnya konsepsi lama tentang pemujaan gunung (arwah nenek moyang), karena tokoh ini mempunyai kedudukan penting dalam situs-situs yang ditemukan di gunung-gunung (WF. Stutterheim,1956: 120-125). Jadi jika perkembangan kultus itu justru terdapat di lerenglereng gunung yang jauh dari pusat kerajaan, kemungkinan adalah untuk mendekatkan diri kepada obyek pemujaannya.

\section{Sukuh Sebuah Bangunan Suci Hindu Dalam Bingkai Budaya Jawa Asli}

Candi Sukuh yang terletak di lereng Gunung Lawu juga menunjukkan adanya pemujaan leluhur. Arca-arca yang ditemukan di kom-pleks candi Sukuh tidak ada yang menggambarkan arca dewa, namun berdasarkan relief-relief ceritanya serta ditemukannya arca lingga menunjukkan bahwa candi itu berlatar belakang agama Hindu (Riboet Darmosoetopo,et al.,1975/1976:66-68) Arca lingga ini tingginya lebih kurang dua meter, yang digambarkan secara naturalis benwujud phallus dengan empat buah bulatan diujungnya. Phallus merupakan gambaran nyata dari lingga. Lingga adalah lambang dewa Çiwa. Pasangan lingga adalah yoni, yang merupakan lambang dewi Uma yaitu çakti Çiwa. Pertemuan lingga dan yoni merupakan lambang penciptaan atau kesuburan. Gambaran tersebut juga terdapat di candi Sukuh, yaitu pada lantai pintu gerbang pertama.

Menurut van der Hoop, unsur kelelakian ( $p$ hallus) merupakan salah satu ciri kebudayaan megalitik di seluruh dunia (Th. van der Hoop, 1938: 106). Pada masa Prasejarah gambar phallus dan vagina sering ditemukan. Di kalangan orang-orang Dayak yang belum terpengaruh kebudayaan Hindu sering digambarkan kelamin laki-laki dan wanita yang diletakkan di depan rumah. Benda-benda itu disebut kelot atau suwuk dalam bahasa Jawa. Fungsi kelot adalah untuk mengusir roh-roh jahat. 
Demikian pula halnya dengan hiasan kepala raksasa (kala) yang terdapat diambang pintu gerbang pertama candi Sukuh, berfungsi sebagai pengusir roh-roh jahat. Kepala raksasa itu lebih mirip kepala raksasa topeng (kedok) daripada dengan hiasan kala di candi-candi dari masamasa sebelumnya. Menurut anggapan pada masa itu, bagian badan yang vital, seperti kepala dan alat kelamin banyak mengandung kekuatan gaib atau mana yang dapat dipergunakan untuk mengusir roh-roh jahat (J. Padmapuspita,t.t:10-11). Selain untuk mengusir roh-roh jahat, penggambaran unsur-unsur seks yang menonjol terutama relief phallus yang berhadapan dengan vagina dianggap sebagai lambang kesuburan

Demikianlah jika memperhatikan lebih dalam mengenai arti simbolis komponen-komponennya, ternyata candi Sukuh tidak hanya berlatar belakang agama Hindu, melainkan tampak juga adanya kepercayaan lama yang berhubungan dengan pemujaan arwah leluhur. Lebih-lebih jika mengamati fungsinya, maka kepercayaan Jawa asli tampak sangat menonjol. Bahkan Stutterheim mengatakan bahwa agama Hindu yang berkembang di Indonesia hanya merupakan selubung di luar saja, sedangkan dalam kehidupan sehari-hari di kalangan rakyat umum pemujaan terhadap anwah nenek moyang merupakan hal utama. Dewa-de wa dan pahlawan-pahlawan dalam cerita Hindu yang masuk di Indone. sia (Jawa) pada permulaan abad pertama masehi dianggap sebagai le luhur manusia yang hidup pada masa-masa kemudian. Roh-roh orang yang telah meninggal mempunyai peranan penting, terutama terhadap bahaya magis yang tidak dapat diduga. Begitu pulalah peninggalan-pe-ninggalan di candi Sukuh lebih dekat kepada pemujaan arwah leluhur, meskipun dipergunakan selubung-selubung seperti cerita-cerita dan upacaraupacara Hindu (WF. Stutterheim,1930:10-11). Melalui penga-matan terhadap relief-relief, susunan bangunan, arca-arca, serta pra-sastinya, dapat diketahui bahwa candi sukuh mempunyai fungsi yang berhubungan dengan upacara pelepasan (ruwatan) dan upacara kesuburan yang dikaitkan dengan pencarian amrta (Ph. Subroto,t.t.: 9).

Relief cerita yang terdapat di candi Sukuh, di antaranya adalah cerita Garudeya dan Çuddhamala. Inti dari kedua cerita itu berisi tentang pelepasan, yaitu suatu usaha untuk membersihkan atau menghilangkan dosa seseorang. Di dalam kesastraan Hindu inti cerita demikian tidak ada, sehingga diduga cerita-cerita tersebut merupakan unsur Indonesia asli yang berhubungan dengan pemujaan terhadap anwah leluhur (Riboet Darmosoetopo,et al., 1975/ 1976: 29-30). Di dalam cerita Garudeya diceritakan tentang kehidupan Winatå yang menjadi budak Kadru, ka- 
rena kalah taruhan mengenai warna ekor kuda Ucchaiçrawa. Winatå dapat bebas dari perbudakan Kadru setelah dapat ditolong anaknya yaitu Garuda dengan cara mencarikan air penghidupan (amrta). Jadi Garudalah yang berhasil meruwat atau melepaskan ibunya dari kutuk Aruna. Aruna adalah anak Winatå juga, yang telah mengutuk ibunya karena dilahirkan dalam keadaan cacad badan akibat kesalahan ibunya (PJ. Zoetmulder,1958:98). Sedangkan kitab Çuddhamala menceritakan tentang kelepasan Dewi Durgå. Nama Çuddhamala sebenarnya merupakan sebutan bagi tokoh Pandawa yang ke lima, yaitu Sahadewa. Çuddhamala berarti bersih dari dosa. Nama ini diberikan kepada Sahadewa karena telah berhasil membersihkan dosa dewi Durgå dari kutuk dewa Çiwa. Dewi Durgå adalah istri Dewa Çiwa, karena berbuat serong terhadap suaminya kemudian dikutuk menjadi raseksi dan harus turun ke dunia. Dia dapat lepas dari kutuk suaminya bila telah diruwat oleh Sahadewa (R.M.Ng. Poerbatjaraka,1952:77).

Unsur pemujaan leluhur dapat dilihat pula pada susunan bangunannya yang berteras-teras ke belakang seperti punden berundak. Bangunan punden berundak pada masa prasejarah mempunyai fungsi utama sebagai tempat pemujaan arwah leluhur. Kata punden berarti tem-pat memuja, sedangkan berundak berarti berteras. Istilah ini diberikan kepada bangunan yang mempunyai fungsi untuk pemujaan, khususnya pemujaan terhadap arwah leluhur (HR. van Heekeren,1960: 76).

Di antara arca-arca yang pernah ditemukan atau pernah ditemukan di candi Sukuh adalah arca Garuda dan arca Bhima. Sebagaimana diketahui kedua tokoh ini adalah tokoh-tokoh pembebas atau penyelamat. Selain itu juga terdapat arca kura-kura, yang mengingatkan pada cerita Samudramanthana, yaitu suatu cerita yang bertema mencari amr ta (Ph. Subroto,t.t:8). Di samping itu juga masih terdapat arca-arca lain yang pengerjaannya sangat sederhana baik bentuk maupun peng-gambaran bagian-bagian tubuh seperti mata melotot, hidung besar, alis dan bibir tebal, serta mulut terbuka. Arca-arca demikian mengingatkan kepada arca-arca tradisi megalitik, yang berfungsi sebagai alat pemu-jaan arwah nenek moyang (Riboet Darmosoetopo,et al., 1975/ 1976:28).

Salah satu prasastinya ada yang berbunyi: "Padamel rikang buku tirta sunya". Prasasti ini terdapat pada salah satu adegan fragmen relief Çuddamala, yaitu pada adegan Bhima melawan raksasa. Kata tirta sunya diduga ada hubungannya dengan ruwatan atau pembebasan dari dosa. Tirta berarti air, sedangkan sunya berarti hilang atau lenyap. Jadi 
tirta sunya dapat berarti air untuk menghilangkan dosa (Riboet Darmosoetopo, et al., 1975/1976:75).

Demikianlah uraian di atas dapat memberikan gambaran secara utuh mengenai fungsi candi Sukuh sebagai sarana pemujaan nenek moyang, yaitu sebagai tempat upacara pelepasan serta mohon kesuburan. Jadi, candi Sukuh walaupun berlatar belakang keagamaan Hindu namun dalam kenyataannya digunakan sebagai tempat upacara yang berhubungan dengan pemujaan arwah nenek moyang.

\section{KEPUSTAKAAN}

Gonda,J.,1970, Siva in Indonesien, Wiener Zeitschrift fur Indische Philosophie.

Harun Hadiwijono,1975,Agama Hindu dan Buddha, Jakarta:BPK Gunung Mulia.

Heekeren,HR. van,1960, Penghidupan dalam zaman Prasedjarah di Indonesia, terj. Amir Sutaarga, Djakarta: Soeroengan.

Hoop, A.N.J.Th.a Th van der, 1938, De Praehistorie, dalam F.W. Stapel, Geschiedenis van Netherlands Indie I, Amsterdam.

Kempers, A.J. Bernet, 1959, Ancient Indonesian Art, Amsterdam: Harvard University Press.

Kern,JHC,1982, Tentang Percampuran Çiwaisme dan Buddhisme di Jawa, sehubungan dengan Syair Jawa Kuna Sutasoma, Çiwa dan Buddha, terj. KITLV- LIPI, Jakarta: Djambatan.

Padmapuspita,J,tt.,Candi Sukuh dan Kidung Sudamala, Proyek Pengembangan Media Kebudayaan, Departemen P dan K RI.

Pigeaud, 1960, Java in the Fourteenth Century I, The Hague: Martinus Nijhoff.

Poerbatjaraka, R.M.Ng. dan Tardjan Hadidjaja, 1952, Kepustakaan Djawa, Djakarta: Djambatan. 
Rassers, 1982, Çiva dan Buddha di Kepulauan Indonesia, Çiva dan Buddha, terj. KITLV-LIPI, Jakarta: Djambatan.

Riboet Darmosoetopo,et al.,1975/1976, Peninggalan-peninggalan Kebudayaan di lereng barat Gunung Lawu, Laporan Penelitian Proyek PPPT - UGM.

Soekmono, 1986, Local Genius dan Perkembangan Bangunan Sakral di Indonesia, dalam Ayatrohaedi, Kepribadian Budaya Bangsa (Local Genius), Jakarta: Pustaka Jaya.

Soewito Santosa,1975,Sutasoma, A study in Javanese Wajrayana New Delhi: International Academy of Indian Culture.

Sri Soejatmi Satari,1975, Seni Rupa dan Arsitektur zaman Klasik di Indonesia, Kalpataru,majalah Arkeologi I.

Stutterheim,W.F.,1930,Gids voor de Oudheden van Soekoeh en Tjeta, Surakarta: de Bliksem.

1931, The Meaning of the Hindu Javanese Candi, Journal of the American Oriental Society vol. 51 Pensylvania:Pensylvania University

1956, An Ancient Javanese Bhima Cult, Studies in Indonesian Archaeology, The Hague: Martinus Nijhoff.

Subroto, Ph., t.t., Permulaan Cerita Çuddhamala dan Garudeya pada Candi Sukuh, Suatu Tinjauan berdasarkan arti dan fungsi relief, Jurusan Arkeologi Fakultas Sastra dan Kebudayaan UGM.

Supomo,1977,Arjunawijaya, A Kakawin of mpu Tantular, The Hague: Martinus Nijhoff.

Teeuw, et al.,1981, Kunjarakarna Dharmakathana, an Old Jav anese poem by mpu Dusun, The Hague: Martinus Nijhoff.

Zoetmulder,P.J.,1958,Sekar Semawur, bunga rampai bahasa Jawa Kuna, Djakarta: Obor.

1983, Kalangwan, Sastra Jawa Kuna selayang pandang, terj.

Dick Hartoko SJ., Jakarta: Djambatan. 